Paulina Maria Nowicka, Radosław Izdebski, Wioleta Kitowska, Janusz Janiec, Joanna Bogusz, Franciszek Radziszewski, Łukasz Henszel

\title{
REVIEW OF MEASLES-RELATED EVENTS RECORDED BY THE NATIONAL IHR FOCAL POINT IN POLAND IN THE YEARS 2016 - 2018
}

\author{
PRZEGLĄD ZDARZEŃ DOTYCZĄCYCH ODRY, ODNOTOWANYCH PRZEZ \\ KRAJOWY PUNKT CENTRALNY DS. MIĘDZYNARODOWYCH PRZEPISÓW \\ ZDROWOTNYCH W POLSCE W LATACH 2016 - 2018
}

\author{
National Institute of Public Health - National Institute of Hygiene in Warsaw \\ Department of Epidemiology of Infectious Diseases and Surveillance \\ Narodowy Instytut Zdrowia Publicznego - Państwowy Zakład Higieny w Warszawie \\ Zakład Epidemiologii Chorób Zakaźnych i Nadzoru
}

\begin{abstract}
Member States of the World Health Organization (WHO), in accordance with the requirements of the International Health Regulations (2005), were obliged to establish National Focal Points for International Health Regulations (IHR NFP), whose task is, among others, consolidating information on public health events of international importance that occur abroad or in the country. The aim of this article is to review information on measles-related events posted on the Event Information Site for IHR National Focal Points, in the Early Warning and Response System (EWRS), received by email directly from other IHR National Focal Points located in WHO member states, and from all organs of the State Sanitary Inspectorate in Poland in the years 2016-2018.

In this time period, the IHR NFP recorded 92 measles-related events of which 38 related to individual cases, 37 to outbreaks of the disease, and 17 involved exposure to a measles case. $36 \%$ of reported events were aviationrelated. The number of events in 2018 has tripled compared to 2017 and increased eightfold in comparison to 2016. The current situation indicates the need to take appropriate actions, including implementation of the National Vaccination Program as well as introducing vaccination interventions.
\end{abstract}

Key words: measles, morbilli, International Health Regulations

\section{STRESZCZENIE}

Państwa członkowskie Światowej Organizacji Zdrowia (WHO) zgodnie z wymogami Międzynarodowych Przepisów Zdrowotnych (2005) zostały zobligowane do powołania Krajowych Punktów Centralnych ds. Międzynarodowych Przepisów Zdrowotnych (KPC ds. MPZ), których zadaniem jest m.in. scalanie informacji dotyczących zdarzeń stanowiących zagrożenie dla zdrowia publicznego o znaczeniu międzynarodowym, które wystąpiły za granicą lub na terenie kraju. Celem niniejszej pracy jest przegląd informacji na temat zdarzeń dotyczących zachorowań na odrę zamieszczonych na stronie Światowej Organizacji Zdrowia dla Krajowych Punktów Centralnych (Event Information Site for IHR National Focal Points), w systemie wczesnego ostrzegania i reagowania (zwanego dalej EWRS), w oparciu o wiadomości e-mail otrzymane bezpośrednio z Krajowych Punktów Centralnych ds. Międzynarodowych Przepisów Zdrowotnych z państw członkowskich WHO oraz z organów Państwowej Inspekcji Sanitarnej w Polsce w latach 2016 - 2018.

KPC ds. MPZ został w tym okresie odnotował 92 zdarzenia dotyczące odry, z czego 38 dotyczyło pojedynczych przypadków zachorowań, 37 - ognisk zachorowań, 17 - narażenia na styczność z osobą chorą na odrę. 36\% zgłoszonych zdarzeń stanowiły zdarzenia lotnicze. Liczba zdarzenia w 2018 roku wzrosła trzykrotnie w porównaniu do roku 2017 i prawie ośmiokrotnie w stosunku do roku 2016. Obecna sytuacja wskazuje na konieczność podjęcia odpowiednich działań, jakim jest m. in. realizacja krajowego Programu Szczepień Ochronnych oraz wdrażanie szczepień interwencyjnych.

Słowa kluczowe: odra, morbilli, Międzynarodowe Przepisy Zdrowotne

(C) National Institute of Public Health - National Institute of Hygiene / Narodowy Instytut Zdrowia Publicznego - Państwowy Zakład Higieny 


\section{INTRODUCTION}

Measles is a highly contagious viral disease, transmitted by droplets or by airborne spread. The patient infects other people from the onset of prodromal symptoms up to 3-4 days after the occurrence of maculopapular rash (1). Despite the availability of a safe and effective vaccine, measles remains an important cause of death among young children around the world.

In May 2012, 194 member states of the World Health Organization adopted the Global Vaccine Action Plan (GVAP) - a framework plan to prevent millions of deaths through wider access to vaccination. One of its goals is the elimination of measles in five WHO regions until 2020 (2). However, according to the WHO assessment on GVAP implementation published in November 2018, four regions had a marked increase in measles incidence since 2017. Outbreaks of measles have been observed in countries with high national immunization coverage. In addition, several countries as well as one WHO region have lost their measles elimination status (3).

In the WHO European Region, in 2018, measles was responsible for the death of 72 people. According to the World Health Organization, 82596 people in 47 out of 53 countries in the region have contracted measles. In countries that provided data on hospitalization, almost 2/3 (61\%) of measles cases were hospitalized. The total number of people infected with the virus in 2018 was the highest in this decade: three times more than in 2017 and 15 times more than in 2016 (4). In 2018, the most cases in the countries of the WHO European region, and at the same time from outside the EU/EEA area occurred in Ukraine (53 218 cases), Serbia (5 076), Israel (2 919), Russia (2 256) and Georgia (2 203) (5).

According to the Risk Assessment of the European Center for Disease Prevention and Control (ECDC) of March 20, 2018, in the period from January 1, 2017 to December 31, 2017, 14600 measles cases were reported from EU/EEA countries under The European Surveillance System (TESSy). This is over three times more than in 2016 (4 642) or in 2015 (4 000) (6).

The epidemiological situation of measles in Poland in 2016 compared to the previous year was characterized by a threefold increase in the number of cases (7), and in 2017 there was a two-fold decrease. The majority of cases occurred in people unvaccinated against measles (8). In 2018, the number of cases in Poland increased again. There were 339 cases of measles, which is more than a five-fold increase compared to 2017 (9).

In order to protect against the spread of all global health threats and reduce their impact, WHO Member States have a legal instrument in the form of the

\section{WSTĘP}

Odra jest chorobą wirusową o wysokim potencjale zakaźnym, szerzy się drogą kropelkową lub powietrzno-kropelkową. Chory zakaża inne osoby w okresie wystąpienia objawów zwiastunowych do 3-4 dni po wystąpieniu plamisto-grudkowej osutki (1). Mimo dostępności bezpiecznej i skutecznej szczepionki, odra pozostaje istotną przyczyną śmierci wśród małych dzieci na całym świecie.

W maju 2012 roku 194 państwa członkowskie Światowej Organizacji Zdrowia przyjęły Global Vaccine Action Plan (GVAP) - ramowy plan zapobiegania milionom zgonów przez upowszechnienie dostępności do szczepień. Jednym z jego celów jest eliminacja odry w pięciu regionach WHO do 2020 roku (2). Jednak według opublikowanej przez WHO w listopadzie 2018 roku oceny realizacji GVAP od 2017 roku w czterech regionach występuje zwiększona zapadalność na odrę. Ogniska odry wystąpiły w państwach o wysokim stanie zaszczepienia populacji. Ponadto kilka państw oraz jeden region WHO utraciły status eliminacji odry (3).

W regionie europejskim WHO w 2018 roku odra spowodowała śmierć 72 osób. Według Światowej Organizacji Zdrowia 82596 osób w 47 z 53 państw regionu zachorowało na odrę. W państwach, które przedstawiły dane dotyczące hospitalizacji, prawie $2 / 3$ (61\%) przypadków odry było hospitalizowanych. Całkowita liczba osób zakażonych wirusem w 2018 r. była najwyższa $\mathrm{w}$ tej dekadzie: 3 razy więcej niż $\mathrm{w}$ roku 2017 i 15 razy więcej, niż w 2016 r (4). W 2018 roku najwięcej przypadków odry w państwach regionu europejskiego WHO, a jednocześnie spoza obszaru UE/ EOG wystąpiło na Ukrainie (53 218 przypadków), w Serbii (5 076), w Izraelu (2 919), Rosji (2 256) i Gruzji (2 203) (5).

Zgodnie z oceną ryzyka Europejskiego Centrum ds. Zapobiegania i Kontroli Chorób (ECDC) z 20 marca 2018 r., w okresie od 1 stycznia 2017 r. do 31 grudnia 2017 r. z państw UE/EOG zgłoszono 14600 zachorowań na odrę w ramach europejskiego systemu nadzoru TESSy (The European Surveillance System). Jest to ponad trzykrotnie więcej, niż w 2016 (4 642) czy w 2015 roku (4 000) (6).

Sytuacja epidemiologiczna odry w Polsce w 2016 r. w porównaniu do roku poprzedniego charakteryzowała się trzykrotnym wzrostem liczby zachorowań (7), a w 2017 r. nastąpił ich dwukrotny spadek. Większość zachorowań wystąpiła u osób nieszczepionych przeciwko odrze (8). W 2018 r. odnotowano w Polsce ponowny wzrost liczby zachorowań. Wystąpiło 339 przypadków odry, co stanowi ponad pięciokrotny wzrost w porównaniu do roku 2017 (9).

W celu ochrony przed rozprzestrzenianiem się wszelkich zagrożeń zdrowotnych w skali globu i ogra- 
International Health Regulations. Adopted in 1969 and aimed at counteracting infectious diseases (plague, cholera, yellow fever, smallpox) and required a revision that took place in 2005. The new International Health Regulations came into force on June 15, 2007. They established a new legal framework for identifying epidemiological threats and enabling rapid response (10). National Focal Points for International Health Regulations (IHR NFP) have been established on their basis. Among the tasks attributed to them are merging data received from other administrative authorities responsible for surveillance and reporting, points of entry, public health institutes and hospitals and sending them, among others to WHO, IHR NFPs from other countries, sanitary-epidemiological stations (11).

\section{MATERIAL AND METHODS}

This review was prepared on the basis of information about events related to measles posted on the Event Information Site for IHR National Focal Points by the World Health Organization (WHO), sent through the Early Warning and Response System (EWRS) established by Decision No 2119/98/EC of the European Parliament and of the Council, emails received directly from IHR National Focal Points from other WHO Member States, and from relevant organs of The Chief Sanitary Inspectorate in Poland in the years 2016-2018. In addition to grouping events according to the year in which they occurred, the study delineates their division into events related to Poland or Polish citizens and concerning only other countries and/or their citizens. The first category includes events concerning individual cases of measles, outbreaks $^{1}$ and exposure to a sick person, and in the second category - events concerning individual cases and outbreaks. In addition, the first category was divided into information about individual cases received from Poland and sent from abroad. Due to the constant growth of air traffic in the world, which affects health security issues, part of the study was devoted to aviation events noted by the IHR National Focal Point in Poland.

\section{RESULTS}

\section{Events regarding measles recorded in the years 2016-2018}

\section{Year 2016}

In 2016, information on measles-related events was sent by Croatia, the Czech Republic, Germany, Poland, Ireland and Japan. They concerned 8 events, half of which were not related to Poland (Figure 1).

\footnotetext{
Outbreaks include information about events in which a minimum of two related and confirmed measles cases occurred in a given area and at a given time.
}

niczenia ich skutków, państwa członkowskie WHO posiadają prawny instrument $\mathrm{w}$ postaci Międzynarodowych Przepisów Zdrowotnych. Zostały one przyjęte w 1969 roku i były ukierunkowane na przeciwdziałanie chorobom zakaźnym (dżumie, cholerze, żółtej gorączce, ospie prawdziwej) i wymagały rewizji, która nastąpiła w 2005 roku. Nowe Międzynarodowe Przepisy Zdrowotne weszły w życie 15 czerwca 2007 roku. Ustanowily nowe ramy prawne rozpoznawania zagrożeń epidemiologicznych i szybkiego reagowania (10). Krajowe Punkty Centralne ds. Międzynarodowych Przepisów Zdrowotnych (KPC ds. MPZ) zostały powołane na ich podstawie. Wśród należących do nich zadań znajduje się scalanie danych otrzymanych od innych organów administracji odpowiedzialnych za nadzór i raportowanie, punktów wejścia, instytutów zdrowia publicznego i szpitali i przesyłanie ich m.in. do WHO, KPC ds. MPZ z innych państw, stacji sanitarno-epidemiologicznych (11).

\section{MATERIAŁ I METODY}

Opracowanie przygotowano w oparciu o informacje na temat zdarzeń dotyczących zachorowań na odrę zamieszczonych na stronie Światowej Organizacji Zdrowia dla Krajowych Punktów Centralnych (Event Information Site for IHR National Focal Points), w ustanowionym decyzją Parlamentu Europejskiego i Rady nr 2119/98/WE z dnia 24 września 1998 r. systemie wczesnego ostrzegania i reagowania (zwanego dalej EWRS), w oparciu o wiadomości e-mail otrzymane bezpośrednio z Krajowych Punktów Centralnych ds. Międzynarodowych Przepisów Zdrowotnych z państw członkowskich WHO oraz z organów Państwowej Inspekcji Sanitarnej w Polsce w latach 20162018. W opracowaniu, oprócz zgrupowania zdarzeń według roku, w którym wystąpiły, zastosowano ich podział na zdarzenia mające związek z Polską lub polskimi obywatelami oraz dotyczące wyłącznie innych państw i/lub ich obywateli. W pierwszej kategorii znalazły się zdarzenia dotyczące pojedynczych przypadków zachorowań na odrę, ognisk ${ }^{1}$ oraz narażeń na kontakt z osobą chorą, a w drugiej - zdarzenia dotyczące pojedynczych przypadków zachorowań oraz ognisk. Ponadto, w pierwszej kategorii zastosowano podział pojedynczych przypadków na zgłoszone z Polski oraz nadesłane z zagranicy. W związku ze stale rosnącym ruchem lotniczym na świecie, który wpływa na kwestie bezpieczeństwa zdrowotnego część opracowania poświęcono odnotowanym przez KPC ds. MPZ zdarzeniom lotniczym.

\footnotetext{
Do ognisk zaliczono informacje o zdarzeniach, w których na określonym obszarze i w określonym czasie doszło do m.in. dwóch powiązanych ze sobą, potwierdzonych zachorowań na odrę.
} 


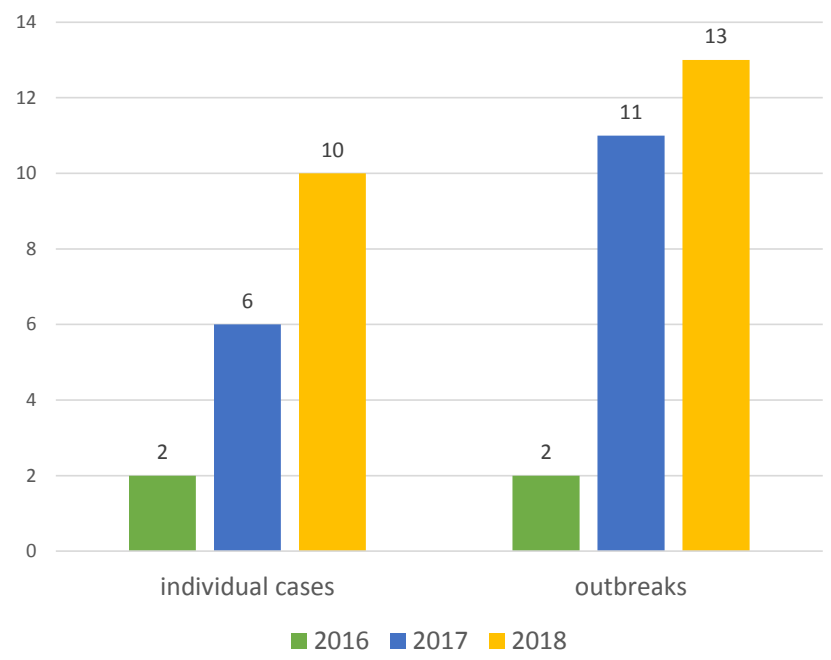

Fig. 1. The number of measles-related events unassociated with Poland or Poles, recorded by the IHR NFP in Poland in the years 2016 - 2018 (source: own study)

Ryc. 1. Liczba zdarzeń niezwiązanych z Polską, ani Polakami, dotyczących odry, które odnotował KPC ds. MPZ w Polsce w latach 2016 - 2018 (źródło: opracowanie własne)

Two of them were news about measles outbreaks in Ireland and Japan. The remaining two concerned cases of measles in a British citizen and a Dutch citizen who traveled by airplane. Of the events related to Poland, three pertained to individual cases and one - an outbreak (Figure 2). This outbreak was noted among migrants, mainly from Chechnya, who applied for asylum in Poland and stayed in refugee centers in the Lublin, Podlasie and Mazovian provinces. In the period from May to the end of December 2016, there were 119 reported measles cases (66 confirmed and 53 likely). Cases were mainly children 16 years of age or younger (113 cases) and only 6 cases occurred in persons over 16 years of age. More than half of the cases concerned persons staying in the reception center located in Biała Podlaska. In response to the incident, vaccinations were implemented for children and adolescents staying in centers and for people who came into contact with the patients. Measles cases among migrants from Chechnya were also reported in Germany and in Belarus.

\section{Year 2017}

In 2017, information on events related to measles was sent by Belgium, Croatia, the Czech Republic, Finland, France, Guinea, Iceland, Hungary, Great Britain, Germany, Norway, Poland, Portugal, Slovakia, Slovenia, Sweden, Taiwan and Venezuela. They related to 21 events. Among those unrelated to Poland and Polish citizens (which accounted for the majority, 17 events) were 11 outbreaks and 6 events

\section{WYNIKI}

\section{Zdarzenia dotyczące odry odnotowane w latach $2016-2018$}

\section{Rok 2016}

W 2016 roku informacje o zdarzeniach związanych z odrą zostały przesłane przez Chorwację, Czechy, Niemcy, Polskę, Irlandię i Japonię. Dotyczyły 8 zdarzeń, z czego połowa nie była związana z Polską (Ryc. 1). Dwa z nich stanowiły wiadomości o ogniskach odry w Irlandii oraz w Japonii. Kolejne dwa dotyczyły przypadków zachorowania obywatela Wielkiej Brytanii i obywatela Holandii, którzy odbywali podróże lotnicze. Ze zdarzeń związanych z Polską trzy dotyczyły pojedynczych zachorowań, a jedno - ogniska (Ryc. 2). Ognisko to odnotowano wśród migrantów, głównie z Czeczenii, którzy ubiegali się o azyl w Polsce i przebywali w ośrodkach dla uchodźców na terenie województw: lubelskiego, podlaskiego i mazowieckiego. W okresie od maja do końca grudnia $2016 \mathrm{r}$. odnotowano 119 przypadków (66 potwierdzonych oraz 53 prawdopodobne) zachorowania na odrę. Zachorowania dotyczyły głównie dzieci do 16 r.ż. włącznie (113 przypadków), zaledwie 6 przypadków zachorowań wystąpiło u osób powyżej 16 r.ż.. Ponad połowa przypadków dotyczyła osób przebywających w ośrodku recepcyjnym znajdującym się na Białej Podlaskiej. W odpowiedzi na zdarzenie wprowadzono szczepienia ochronne dzieci i młodzieży przebywających w ośrodkach oraz szczepienia osób z kontaktu z chorymi. Zachorowania na odrę wśród migrantów z Czeczenii zostały odnotowane również w Niemczech oraz w Białorusi.

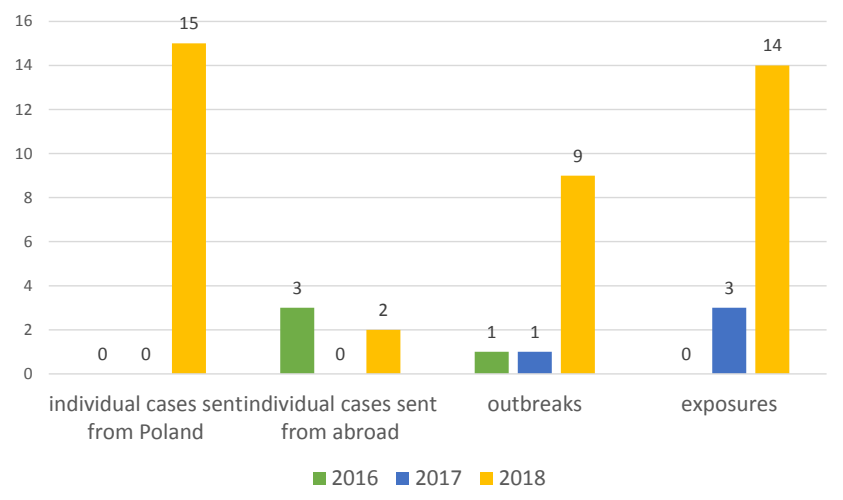

Fig. 2. The number of measles-related events associated with Poland and/or Poles, recorded by the IHR NFP in Poland in the years 2016-2018 (source: own study)

Ryc. 2. Liczba zdarzeń związanych z Polską i/lub Polakami, dotyczących odry, które odnotował KPC ds. MPZ w Polsce w latach 2016-2018 (źródło: opracowanie własne) 
concerning individual cases of disease (Fig. 1). The biggest in terms of the number of confirmed cases in the outbreak of measles reported in 2017 was the outbreak in Romania. According to information from the National Center for Surveillance and Control of Infectious Diseases in Romania in this country, in the period from January 1, 2016 to March 31, 2017, there were 4025 cases of measles, 18 of which were fatal (12). In particular, cases occurred in areas where the inoculation status was low (they occurred in 37 out of 42 districts). Most of them were reported in the western part of the country, in particular in Caraş-Severin (a district located in south-western Romania). According to the 2017 ECDC risk assessment, outbreaks linked to the outbreak in Romania were reported in three EU Member States. The high likelihood of further transmission of infection in Romania posed a risk of the introduction of contagious diseases in other EU / EEA countries.

Among all the measles outbreaks noted in 2017, the outbreak in Venezuela was the most geographically distant from Poland. The last confirmed case of measles was recorded there in 2012, and in October 2016 Venezuela obtained the measles elimination status. Since the occurrence of the first case in June 2017 to March 2018, 1006 confirmed cases were reported, including 2 deaths. The highest number of cases was observed at the turn of September and October in 2017 and at the turn of February and March in 2018. The majority $(67 \%)$ of confirmed cases were recorded in Bolívar (the state with the highest cumulative incidence). Cases had also been reported in 7 other states (Apure, Anzoátegui, Delta Amacuro, Capital District, Miranda, Monagas and Vargas). As part of intervention measures, a national rapid response plan was developed to stop transmission of the virus. Rapid response teams were activated at the state, regional and city level, epidemiological surveillance was introduced, a vaccination strategy was implemented, and medical personnel training was organized.

Taking into account the number of confirmed cases, the third largest outbreak of measles was in Belgium. The outbreak began on December 20, 2016. Since then, until March 12, 2017, there were a total of 177 measles cases, of which 96 were laboratory confirmed. The identified strain resembled the one that appeared in late 2016 in Romania, Italy and Austria. The age distribution of cases was as follows: $27 \%$ concerned children under the age of five, $23 \%$ were children aged $5-14$, while the remaining $50 \%$ of cases were diagnosed in people between 15 and 45 years of age. 18 cases were also reported among healthcare workers. Most of the cases were amongst people who were not vaccinated or had an unknown history of vaccination.

\section{Rok 2017}

W 2017 roku informacje dotyczące zdarzeń związanych z odrą zostały przesłane przez Belgię, Chorwację, Czechy, Finlandię, Francję, Gwineę, Islandię, Węgry, Wielką Brytanię, Niemicy, Norwegię, Polskę, Portugalię, Słowację, Słowenię, Szwecję, Tajwan i Wenezuelę. Dotyczyły 21 zdarzeń. Wśród niezwiązanych z Polską, ani polskimi obywatelami (które stanowiły większość, bo aż 17 zdarzeń) znalazło się 11 ognisk oraz 6 zdarzeń dotyczących pojedynczych przypadków zachorowań (Ryc. 1). Największych pod względem liczby potwierdzonych przypadków ogniskiem odry zgłoszonym w 2017 roku było ognisko w Rumunii. Zgodnie z informacją z Narodowego Centrum Nadzoru i Kontroli Chorób Zakaźnych w Rumunii na terenie tego państwa, w okresie od 1 stycznia 2016 roku do 31 marca 2017 roku, odnotowano 4025 przypadków odry, w tym 18 zakończonych zgonem (12). Zachorowania te występowały zwłaszcza na obszarach, gdzie stan zaszczepienia był niski (wystąpiły w 37 z 42 okręgów). Najwięcej z nich było zgłoszonych w zachodniej części kraju, a w szczególności w Caraş-Severin (okręg położony w południowo-zachodniej Rumunii). Według oceny ryzyka ECDC z 2017 roku w 3 państwach członkowskich Unii Europejskiej odnotowano ogniska powiązane z ogniskiem w Rumunii. Występujące w Rumunii wysokie prawdopodobieństwo dalszej transmisji zakażenia stwarzało ryzyko pojawienia się zawleczonych zachorowań w innych państwach UE/ EOG.

Najbardziej odległym od Polski ogniskiem odry zgłoszonym w 2017 roku było ognisko w Wenezueli. Ostatni potwierdzony przypadek odry odnotowano tam w 2012 roku, a w październiku 2016 roku ogłoszono Wenezuelę państwem, w którym doszło do eliminacji odry. Od wystąpienia pierwszego przypadku w czerwcu 2017 roku do marca 2018 roku poinformowano o 1006 potwierdzonych zachorowaniach, w tym 2 śmiertelnych. Najwyższą liczbę zachorowań zaobserwowano na przełomie września i października w 2017 roku oraz na przełomie lutego i marca w 2018 roku. Większość (67\%) potwierdzonych zachorowań odnotowano w Bolívar (stan o największej skumulowanej zapadalności). Zachorowania odnotowano również w 7 innych stanach (Apure, Anzoátegui, Delta Amacuro, Capital District, Miranda, Monagas i Vargas). W ramach interwencji opracowano państwowy plan szybkiego reagowania $\mathrm{w}$ celu przerwania transmisji wirusa. Uruchomiono zespoły szybkiego reagowania na poziomie państwa, regionów i miast, wprowadzono nadzór epidemiologiczny, wdrożono strategię działań w zakresie szczepień oraz zorganizowano szkolenia personelu medycznego. 
There were no fatal cases reported in the outbreak, but severe cases occurred in all age groups. A person considered to be the index case traveled to Romania during the incubation period of the disease.

Among the eight remaining, unassociated with Poland outbreaks, confirmed measles cases counted from 4 to 47 cases.

One of the more significant events related to measles in Poland in 2017, about which the IHR National Focal Point was informed, was an outbreak of this disease in the city of Poznań. There was a total of 22 laboratory confirmed measles cases reported. The majority of patients were of Roma origin (17 people), while the remaining 5 were Poles (including one doctor). As part of the campaign aimed at limiting the spread of the outbreak, measles vaccination was carried out amongst the Roma community living in Poznań (29 people were vaccinated).

In addition to the aforementioned outbreak, among the incidents related to Poland or Polish citizens in 2017 there were 3 where exposure to a sick person occurred (Figure 2).

\section{Year 2018}

Only in January 2018, 1073 measles cases from all EU/EEA countries, with the exception of Malta, were reported to the European Center for Disease Prevention and Control. Between January and March 2018, large outbreaks of measles occurred in Greece (1 131 cases), Romania (757), France (429), Italy (168) and Portugal (145), while smaller outbreaks were found in Belgium (5 cases), the Czech Republic (23), Germany (33), Ireland (44), Latvia (9), Norway (4), Poland (17) and Sweden (14 cases) (6).

In 2018 information on events related to measles was sent by Australia, Austria, Belgium, Brazil, Croatia, the Czech Republic, Denmark, Finland, France, Georgia, Spain, Latvia, Ireland, Japan, Malta, Germany, Poland, Portugal, Slovakia, Switzerland, Taiwan, Venezuela, Great Britain. They corresponded to 63 events. Among those unrelated to Poland and Poles, there were 13 outbreaks and 10 events concerning individual measles cases (Fig. 1). On the other hand, among events related to Poland and Poles there were 9 outbreaks, 15 events received from Poland related to individual measles cases, 2 events received from abroad related to individual cases, and 14 concerning exposure to a person suffering from measles (Fig. 2). Table I presents the number of confirmed cases of measles from the events associated with Poland and/or Poles, by nationality.

From information posted in the EWRS system by the IHR National Focal Point in France, it appears that in the period from January 2018 to April 24, 2018,
Trzecim pod względem liczby potwierdzonych zachorowań było ognisko odry w Belgii. W tym ognisku od 20 grudnia do 12 marca 2017 roku odnotowano łącznie 177 przypadków odry, z czego 96 zostało potwierdzonych laboratoryjnie. Zidentyfikowany szczep przypominał ten, który pojawił się pod koniec 2016 roku w Rumunii, Włoszech i Austrii. Rozkład wiekowy zachorowań przedstawiał się następująco: $27 \%$ z nich dotyczyło dzieci poniżej 5 roku życia, 23\% stanowiły dzieci w wieku 5-14 lat, natomiast pozostałe 50\% zachorowań wystąpiło u osób pomiędzy 15 a 45 r.ż. Odnotowano również 18 zachorowań wśród pracowników służby zdrowia. Większość zachorowań dotyczyła osób niezaszczepionych lub z nieznaną historią szczepień. W ognisku nie odnotowano przypadków śmiertelnych, lecz we wszystkich grupach wiekowych wystąpiły zachorowania o ciężkim przebiegu. Osoba uznana za przypadek indeksowy podróżowała do Rumunii podczas okresu inkubacji choroby.

Osiem pozostałych, niezwiązanych z Polską ognisk liczyło od 4 do 47 potwierdzonych przypadków odry.

Jednym $\mathrm{z}$ istotniejszych zdarzeń dotyczących odry w Polsce w 2017 roku, o którym poinformowano KPC ds. MPZ, było ognisko tej choroby w Poznaniu. Odnotowano tam łącznie 22 potwierdzone laboratoryjnie przypadki. Większość chorych stanowiły osoby pochodzenia romskiego (17 osób), natomiast pozostałe 5 to Polacy (w tym jeden lekarz). W ramach akcji mającej na celu ograniczenie rozprzestrzeniania się ogniska przeprowadzono szczepienia ochronne przeciw odrze w społeczności romskiej zamieszkującej na terenie miasta Poznania (zaszczepiono 29 osób).

Oprócz wspomnianego ogniska, wśród zdarzeń związanych z Polską lub polskimi obywatelami w 2017 roku znalazły się 3 narażenia na kontakt z osobą chorą (Ryc. 2).

\section{Rok 2018}

W styczniu 2018 r. do Europejskiego Centrum ds. Zapobiegania i Kontroli Chorób zgłoszono 1073 przypadki odry ze wszystkich państw UE/EOG z wyjątkiem Malty. Między styczniem a marcem 2018 roku duże ogniska odry wystąpiły w Grecji (1 131 przypadków), Rumunii (757), Francji (429), Włoszech (168) i Portugalii (145), natomiast liczące mniej przypadków ogniska stwierdzono w Belgii (5 przypadków), Czechach (23), Niemczech (33), Irlandii (44), Łotwie (9), Norwegii (4), Polsce (17) i Szwecji (14 przypadków) (6).

W 2018 roku informacje dotyczące zdarzeń związanych z odrą zostały przesłane przez Australię, Austrię, Belgię, Brazylię, Chorwację, Czechy, Danię, Finlandię, Francję, Gruzję, Hiszpanię, Łotwę, Irlandię, Japonię, Maltę, Niemcy, Polskę, Portugalię, Sło- 
there were 1999 measles cases reported there. Cases occurred in many regions of France, but $49 \%$ of them were reported in the Nouvelle-Aquitaine region. The highest incidence rate was observed in children under one year of age (20.5 cases/100 000 population), and the hospitalization rate was $20 \%$. The majority ( $88 \%)$ of cases were among unvaccinated people or those vaccinated with only one dose of vaccine.

Table I. The number of confirmed cases of measles from the events associated with Poland and/or Poles, by nationality

Tabela I. Liczba potwierdzonych przypadków odry ze zdarzeń związanych z Polską i/lub Polakami $\mathrm{z}$ podziałem na narodowości

\begin{tabular}{|c|c|c|c|}
\hline $\begin{array}{c}\text { Nationality of the } \\
\text { confirmed measles cases }\end{array}$ & \multicolumn{2}{c}{$\mathbf{2 0 1 6}$} & \multicolumn{2}{c|}{$\mathbf{2 0 1 7}$} & $\mathbf{2 0 1 8}$ \\
\hline German & 1 & & \\
\hline Russian & 15 & & 5 \\
\hline Czech & 1 & & \\
\hline Portuguese & & 1 & \\
\hline Roma & & 2 & \\
\hline Australian & & 1 & \\
\hline British & & 1 & \\
\hline Austrian & & 1 & \\
\hline Ukrainian & & & 25 \\
\hline Italian & & & 1 \\
\hline Dutch & & & 1 \\
\hline Vietnamese & & & 1 \\
\hline Polish & & 1 & 12 \\
\hline Unknown & 52 & 1 & 18 \\
\hline
\end{tabular}

Among the events noted by the IHR NFP in 2018, the most geographically distant outbreaks in relation to Poland happened in Brazil and Japan. According to information from May 2018, there were 693 suspected cases of measles in Brazil, of which 103 were confirmed. Two people died. One laboratory confirmed case concerned a 1-year-old, unvaccinated girl who had traveled to several European countries. Of the 81 cases confirmed in the state of Roraima bordering Venezuela, 55 cases $(68 \%)$ concerned Venezuelans, including indigenous people (29 cases). Confirmed cases concerned people aged from 6 months to 30 years. Laboratory analysis of confirmed cases identified a genotype identical to that identified in Venezuela in 2017. Among the actions undertaken, a vaccination campaign, intensified epidemiological surveillance, strengthening of the laboratory network and training of health care workers were listed. The outbreak reported in Japan was smaller than the Brazilian one in terms of the number of cases - 115 cases were recorded there (as of 16 May 2018). No deaths were reported. The index wację, Szwajcarię, Tajwan, Wenezuelę, Wielką Brytanię. Dotyczyły 63 zdarzeń. Wśród niezwiązanych z Polską, ani Polakami było 13 ognisk oraz 10 zdarzeń dotyczących pojedynczych przypadków zachorowań (Ryc. 1). Ponadto wśród związanych z Polską i Polakami znalazło się 9 ognisk, 15 zdarzeń dotyczących pojedynczych przypadków zachorowań przesłanych z Polski, 2 zdarzenia dotyczące pojedynczych przypadków zachorowań przesłanych z zagranicy oraz 14 dotyczących narażeń na kontakt $\mathrm{z}$ osobą chorą na odrę (Ryc. 2). Tabela I przedstawia liczbę potwierdzonych przypadków odry ze zdarzeń związanych z Polską i/ lub Polakami z podziałem na narodowości.

$\mathrm{Z}$ informacji zamieszczonych $\mathrm{w}$ systemie EWRS przez KPC ds. MPZ we Francji wynika, że w okresie od stycznia 2018 r. do 24 kwietnia 2018 r. odnotowano tam 1999 przypadków zachorowań na odrę. Zachorowania występowały w wielu regionach Francji, lecz 49\% przypadków odnotowano w regionie Nouvelle-Aquitaine. Najwyższą zapadalność zaobserwowano u dzieci poniżej 1 roku życia $(20,5$ przypadków/100 000 populacji), a wskaźnik hospitalizacji wynosił $20 \%$. Większość (88\%) zachorowań wystąpiła wśród osób niezaszczepionych lub zaszczepionych tylko jedną dawką szczepionki.

Do najbardziej odległych geograficznie od Polski ognisk, które odnotowano przez KPC ds. MPZ zdarzeń w 2018 roku należy zaliczyć ogniska w Brazylii oraz w Japonii. Według informacji z maja 2018 roku w Brazylii odnotowano 693 podejrzane przypadki odry, z których 103 potwierdzono. Dwie osoby zmarły. Jeden potwierdzony laboratoryjnie przypadek dotyczył rocznej, niezaszczepionej przeciwko odrze dziewczynki, która podróżowała do kilku europejskich państw. Spośród 81 przypadków potwierdzonych $\mathrm{w}$ graniczącym $\mathrm{z}$ Wenezuelą stanie Roraima 55 przypadków (68\%) dotyczyło Wenezuelczyków, w tym członków plemion indiańskich (29 przypadków). Potwierdzone przypadki dotyczyły osób w wieku od 6 miesięcy do 30 lat. Badania potwierdzonych przypadków wykazały genotyp identyczny z tym, jaki krążył w Wenezueli w 2017 r. Wśród podjętych działań wymieniono kampanię szczepień, zintensyfikowany nadzór epidemiologiczny, wzmocnienie sieci laboratoryjnej i szkolenie pracowników opieki zdrowotnej.

Zgłoszone ognisko w Japonii było mniejsze pod względem liczby przypadków od brazylijskiego - zarejestrowano ich tam 115 (stan na dzień 16 maja 2018 roku). Nie odnotowano zgonów. Przypadkiem indeksowym była osoba, która przyleciała z Tajwanu (Chiny) i podróżowała po prefekturze Okinawa w trakcie okresu zakaźności. Warto zaznaczyć, że w marcu 2015 r. ogłoszono w Japonii eliminację odry. Niemniej jednak ogniska spowodowane importowanymi przypadkami $\mathrm{z}$ innych regionów mogą sporadycznie występować. 
case was a person who flew in from Taiwan (China) and traveled around the Okinawa prefecture during their infectious period. It is worth noting that in March 2015 , the elimination of measles was announced in Japan. However, outbreaks caused by imported cases from other regions may occasionally occur.

Outbreaks that should be mentioned due to their size and occurrence in the neighboring countries of Poland are: an outbreak in Slovakia and an outbreak in Germany. In the first of these, from May 7, 2018 to July 11,2018 , there were 192 cases of measles reported ( 85 confirmed, 107 probable) in the eastern part of the country and among the Roma population. 155 people were hospitalized, 4 cases were imported from the UK, and 9 cases were reported among health care workers. Most cases were recorded among people in the age group 15-19 years (43 cases) and 5-9 years (39 cases). In turn, the second of these outbreaks was connected with the International Youth Festival held in Cologne from May 19 to 23, 2018, in which about 400 people from various countries took part. In total, there were 108 measles cases diagnosed there (the age range of people who became ill was 6 months - 62 years). Most of the participants came from Germany (298 cases), there were also people from Hungary (11 cases), Austria (10), the Netherlands (8), Finland (5), Italy (2), the Czech Republic (2), Belgium (2) and Great Britain (1 case). The remaining people (64) came from countries outside the EU/EEA. An outbreak of measles in Cologne was already ongoing at the beginning of 2018, however, after comparing the genotypes of the virus, it was assumed that cases of measles associated with the International Youth Festival were not related to it.

One of the major outbreaks that occurred in Poland (and which were reported to the IHR NFP) in 2018 was the outbreak in Pruszków. From October 10, 2018, the employees of the Epidemiology Department of the local sanitary-epidemiological station conducted epidemiological surveillance of 17 patients, including 9 people with laboratory confirmed measles, 3 people waiting for the laboratory results, 4 classified on the basis of clinical symptoms and 1 suspected case of the disease. In total, four sick persons were hospitalized, including three children aged 1 year, 5 years, 6 years and one adult at the age of 31 years. During the epidemiological investigation, about 200 exposed people were identified as contacts of the patients.

\section{Aviation events}

The most dynamically developing branch of transport is air transport (13). Due to the increasing frequency of travel by this method of transportation, there is a high probability of disease spread and
Ogniska, o których należy wspomnieć ze względu na ich wielkość oraz wystąpienie na terenie państw sąsiadujących z Polską to: ognisko w Słowacji oraz ognisko w Niemczech. W pierwszym z nich w okresie od 7 maja 2018 roku do 11 lipca 2018 roku, odnotowano 192 przypadki odry ( 85 potwierdzonych, 107 prawdopodobnych) we wschodniej części kraju oraz wśród populacji Romów. Hospitalizowano 155 osób, 4 przypadki były zawleczone z Wielkiej Brytanii, 9 przypadków wystąpiło wśród pracowników opieki zdrowotnej. Najwięcej przypadków (43) odnotowano wśród osób w grupie wieku 15-19 lat oraz 5-9 lat (39 przypadków).

Drugie $\mathrm{z}$ wymienionych ognisk było związane z odbywającym się od 19 do 23 maja 2018 roku, w szkole w Kolonii Międzynarodowym Festiwalem Młodzieży, w którym wzięło udział około 400 osób z różnych państw. Ogółem odnotowano tam 108 zachorowań na odrę (w przedziale wieku osób od 6 miesięcy - 62 lat). Większość uczestników pochodziła z Niemiec (298 osób), były tam również osoby pochodzące z Węgier (11 osób), Austrii (10), Holandii (8), Finlandii (5), Włoch (2), Czech (2), Belgii (2) i Wielkiej Brytanii (1 osoba). Pozostałe osoby (64) pochodziły z państw spoza UE/EOG. Ognisko odry w Kolonii pojawiło się już na początku 2018 roku, jednak po porównaniu genotypów wirusa założono, że przypadki odry związane z Międzynarodowym Festiwalem Młodzieży nie są z nim powiązane.

Jednym $\mathrm{z}$ większych ognisk, jakie wystąpiły na terenie Polski (i które zostały zgłoszone do KPC ds. MPZ) w 2018 roku było ognisko w Pruszkowie. Od dnia 10.10.2018 r. pracownicy Sekcji Epidemiologii Powiatowej Stacji Sanitarno-Epidemiologicznej objęli nadzorem epidemiologicznym 17 osób chorych, w tym 9 osób z potwierdzonymi badaniami laboratoryjnymi zachorowań na odrę, 3 osoby w trakcie oczekiwanych wyników, 4 na podstawie objawów klinicznych i 1 podejrzenie zachorowania. Ogółem hospitalizowano cztery osoby chore, w tym troje dzieci w wieku 1 r.ż., 5 lat, 6 lat oraz 1 osobę dorosłą w wieku 31 lat. $\mathrm{W}$ trakcie prowadzonego dochodzenia epidemiologicznego ustalono około 200 osób narażonych, które były w kontakcie z chorymi.

\section{Zdarzenia lotnicze}

Najbardziej dynamicznie rozwijającą się gałęzią transportu jest transport lotniczy (13). W związku z coraz częstszym wybieraniem przez podróżnych tego środka transportu istnieje wysokie prawdopodobieństwo rozprzestrzeniania się chorób oraz wystąpienia narażenia na kontakt z osobą chorą podczas lotu (14). Na rycinie 4 przedstawiono liczbę zdarzeń lotniczych dotyczących odry, które odnotował w okresie od 2016 
exposure to contact during flight (14). Figure 4 shows the number of measles-related aviation events notified by the IHR NFP in Poland in the years $2016-2018$, divided into years and into European flights, continental flights - other than European, and intercontinental flights.

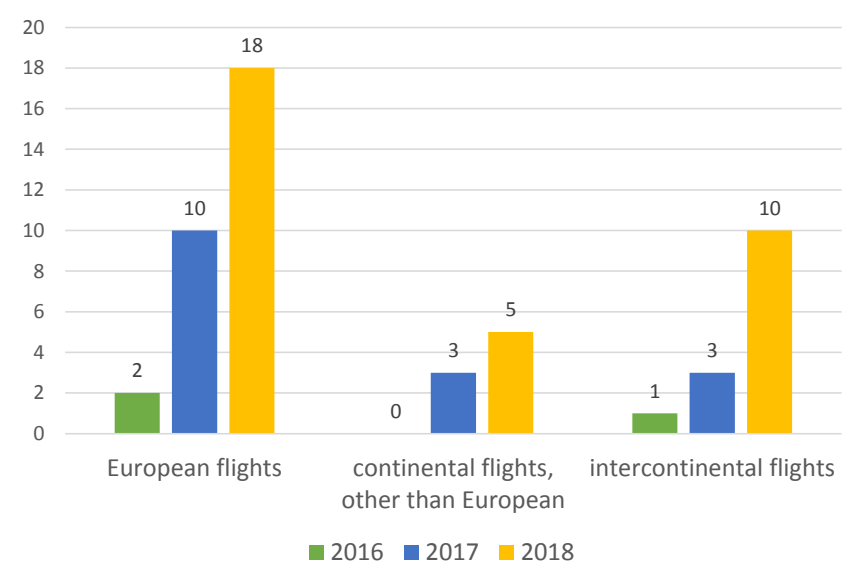

Fig. 4 The number of measles-related aviation events recorded by the IHR NFP in Poland in the years 2016-2018 (source: own study)

Ryc. 4 Liczba zdarzeń lotniczych dotyczących odry, które odnotował KPC ds. MPZ w Polsce w latach 2016-2018 (źródło: opracowanie własne) do 2018 r. KPC ds. MPZ, z podziałem na lata oraz na loty europejskie, kontynentalne - inne, niż europejskie oraz międzykontynentalne.

W tabeli II zestawiono wszystkie zdarzenia lotnicze dotyczące Polski w okresie od 2016 do 2018 r. odnotowane przez KPC ds. MPZ, podczas których doszło do narażenia na kontakt $\mathrm{z}$ osobą chorą na odrę podczas lotu lub identyfikacji przypadku indeksowego z rozróżnieniem na rodzaj lotu i narodowości.

W 2016 r. do KPC ds. MPZ wpłynęły 3 zdarzenia lotnicze z Chorwacji, Islandii i Japonii. Spośród wszystkich zdarzeń dwa dotyczyły zachorowań na odrę osób, które w okresie zaraźliwości podróżowały samolotem. Pierwszym tego typu zdarzeniem było zachorowanie na odrę osoby, która odbyła lot europejski z Amsterdamu (Holandia) do Dubrownika (Chorwacja) w dniu 10 lipca 2016 r. Drugie zdarzenie zgłoszone z Islandii dotyczyło przypadku odry, u osoby która w okresie zakaźności odbyła jeden lot międzykontynentalny z Montrealu (Kanada) do Islandii w dniu 4 sierpnia 2016 oraz lot europejski z Keflaviku (Islandia) do Londynu (Wielka Brytania) w dniu 5 sierpnia 2016. Wśród osób z kontaktu podczas lotu z Keflaviku do Londynu zidentyfikowano jeden prawdopodobny przypadek odry. Jedno spośród trzech zgłoszonych zdarzeń lotniczych miało miejsce na lotnisku Kansai w Osace (Japonia).

Table II. Aviation events recorded by the IHR NFP in Poland between years 2016 and 2018, during which Poles/Polish residents were exposed to the measles case during the flight and aviation events in which Poles were index cases.

Tabela II. Odnotowane w okresie od 2016 do 2018 r. przez KPC ds. MPZ zdarzenia lotnicze, podczas których doszło do narażenia osób z Polski/zamieszkałych na terenie Polski na kontakt z osobą chorą na odrę podczas lotu oraz zdarzeń lotniczych, w których Polak/Polka był/a przypadkiem indeksowym.

\begin{tabular}{|c|c|c|c|c|c|c|}
\hline \multirow[b]{2}{*}{ Year } & \multirow{2}{*}{$\begin{array}{l}\text { Nationality of } \\
\text { index case }\end{array}$} & \multirow{2}{*}{$\begin{array}{c}\text { Number of exposed } \\
\text { Polish citizens/residents }\end{array}$} & \multirow{2}{*}{$\begin{array}{l}\text { Index } \\
\text { case }\end{array}$} & \multicolumn{3}{|c|}{ Flights } \\
\hline & & & & European & $\begin{array}{l}\text { Continental (other } \\
\text { than European) }\end{array}$ & Intercontinental \\
\hline 2016 & & No reported exposure & & & & \\
\hline \multirow{3}{*}{2017} & Unknown & 2 & 1 & & 1 & 1 \\
\hline & Unknown & 1 & 1 & 1 & & \\
\hline & Unknown & 1 & 1 & & & 1 \\
\hline \multirow{14}{*}{2018} & Unknown & 10 & 1 & 1 & & \\
\hline & Unknown & 1 & 1 & & 1 & \\
\hline & Unknown & 3 & 1 & 1 & & \\
\hline & Unknown & 2 & 1 & 1 & & \\
\hline & Unknown & 1 & 1 & & & 1 \\
\hline & Unknown & 16 & 1 & 1 & & 1 \\
\hline & Unknown & 2 & 1 & 2 & & \\
\hline & Polish & & 1 & 1 & & \\
\hline & Polish & & 1 & 1 & & \\
\hline & Australian & 1 & 1 & & & 1 \\
\hline & USA & 1 & 1 & 1 & & \\
\hline & Ukrainian & 12 & 1 & 2 & & \\
\hline & Danish & 3 & 1 & & 1 & 1 \\
\hline & Polish & & 2 & 1 & & \\
\hline
\end{tabular}


Table II summarizes all aviation events noted by the IHR NFP in Poland between years 2016 and 2018, during which Poles/Polish residents were exposed to measles cases during flight or where there was identification of an index case, with a distinction between flight type and specification of nationality.

In 2016, 3 aviation incidents from Croatia, Iceland and Japan were recorded by the IHR NFP. Of all the events, two were related to measles cases in people who traveled by plane during the infectious period. The first event of this type was a measles case in a person who took a European flight from Amsterdam (the Netherlands) to Dubrovnik (Croatia) on July 10, 2016. The second incident reported from Iceland concerned a measles case in a person who, during the infectious period, had one intercontinental flight from Montreal (Canada) to Iceland on August 4, 2016 and a European flight from Keflavik (Iceland) to London (United Kingdom) on August 5, 2016. Among the contact persons on the flight from Keflavik to London, one probable case of measles was identified. The last of the three reported aviation events took place at the Kansai airport in Osaka (Japan). The IHR NFP was notified about this incident due to the observed increase in measles cases in Japan. Between January 1 and August 24, 2016, there were 32 cases of measles reported in this country. Of these, 4 patients were at the Kansai airport in Osaka and 1 was employed there. In March 2015, Japan was recognized as a country that managed to eliminate measles, however, the occurrence of these cases is not unusual. The risk of a major outbreak was low due to the implementation by Japan of appropriate measures including the early detection of cases in the surveillance of measles. In 2016, no aviation events with the participation of Poles or people residing in the territory of Poland were sent to the National Focal Point for International Health Regulations.

In 2017, 7 aviation incidents from Taiwan, Germany ( 2 events), Slovenia, Norway, the USA and Iceland were received by the IHR NFP in Poland. Of all these events, three involved exposure of Polish citizens/residents during an airplane flight to a person suffering from measles (Table II). In total, there were 4 people from Poland who were exposed to a person suffering from measles during a flight. The other aviation incidents that were notified to the IHR NFP were events without the participation of Poles regarding measles cases in people who traveled by plane during the infectious period. The first event of this type concerned an uninoculated citizen of Germany who had two European flights from Cologne/ Bonn (Germany) to Milan (Italy) and from Milan to Cologne/Bonn. The second event involved the onset of measles in a Syrian child aged 1 who travelled by two
KPC ds. MPZ został powiadomiony o tym zdarzeniu w związku ze wzrostem zachorowań na odrę w Japonii. W okresie pomiędzy 1 stycznia a 24 sierpnia 2016 r. odnotowano 32 przypadki odry w tym kraju. Spośród nich 4 chorych przebywało na lotnisku Kansai w Osace, a 1 był na nim zatrudniony. W marcu 2015 r. Japonia uznana została za państwo, któremu udało się wyeliminować zachorowania na odrę, jednakże wystąpienie tych zachorowań nie jest czymś niezwyczajnym. Ryzyko wystąpienia dużego ogniska było niskie z uwagi na wdrożenie przez Japonię odpowiednich działań, w tym wczesnego wykrywania przypadków w nadzorze nad odrą. W 2016 r. do Krajowego Punktu Centralnego ds. Międzynarodowych Przepisów Zdrowotnych nie wpłynęły żadne zdarzenia lotnicze z udziałem Polaków lub osób zamieszkałych na terenie kraju.

W 2017 r. do KPC ds. MPZ wpłynęło 7 zdarzeń lotniczych: z Tajwanu, Niemiec (2 zdarzenia), Słowenii, Norwegii, USA oraz Islandii. Spośród wszystkich zdarzeń trzy dotyczyły narażenia osób z Polski lub zamieszkałych na terenie kraju na kontakt z osobą chorą na odrę podczas lotu (Tab. II). Łącznie odnotowano 4 osoby z Polski, które zostały narażone na styczność $\mathrm{z}$ osobą chorą na odrę podczas lotu. Pozostałe zdarzenia lotnicze, o których został powiadomiony KPC ds. MPZ, stanowiły zdarzenia bez udziału Polaków dotyczące zachorowań na odrę osób, które w okresie zaraźliwości podróżowały samolotem. Pierwsze tego typu zdarzenie dotyczyło niezaszczepionego obywatela Niemiec, który odbył dwa loty europejskie z Kolonii/Bonn (Niemcy) do Mediolanu (Włochy) oraz z Mediolanu (Włochy) do Kolonii/Bonn (Niemcy). To zachorowanie na odrę syryjskiego dziecka dotyczyło wystąpienia zachorowania na odrę u syryjskiego dziecka w wieku 1 roku, które odbyło dwa loty europejskie z Aten (Grecja) do Belgradu (Serbia) oraz Belgradu (Serbia) do Lublany (Słowenia). Trzecie zdarzenie dotyczyło wystąpienia zachorowania na odrę u osoby, która odbyła cztery loty europejskie z Grozny (Czeczenia) przez Moskwę (Rosja), Rygę (Łotwa) i Oslo (Norwegia) do Stavanger (Norwegia). Czwarte zdarzenie lotnicze związane było zachorowaniem na odrę pielęgniarki z Islandii, pracującej w Bangladeszu, która w okresie zaraźliwości odbyła jeden lot europejski, dwa loty kontynentalne oraz jeden międzykontynentalny. Podróż obejmowała Koks Badźar (Bangladesz), Dhakę (Bangladesz), Dubaj (Zjednoczone Emiraty Arabskie), Oslo (Norwegia) i Islandię.

W 2018 r. do KPC ds. MPZ wpłynęły 23 zdarzenia lotnicze z Łotwy, Gruzji, Polski (3 zdarzenia), Belgii, Czech (2), Tajwanu, Australii (2), Finlandii, Wielkiej Brytanii, Malty, Szwajcarii (3), Danii, Portugalii (3), Słowacji, Hiszpanii. Spośród wszystkich zdarzeń 11 dotyczyło narażenia osób z Polski lub zamieszkałych 
European flights from Athens (Greece) to Belgrade (Serbia) and Belgrade to Ljubljana (Slovenia). The third event concerned the onset of measles in a person who had four European flights from Grozny (Chechnya) via Moscow (Russia), Riga (Latvia) and Oslo (Norway) to Stavanger (Norway). The fourth aviation incident was related to a measles case in a nurse from Iceland working in Bangladesh, who had one European flight, two continental flights and one intercontinental flight during the infectious period. The trip included Cox's Bazar (Bangladesh), Dhaka (Bangladesh), Dubai (United Arab Emirates), Oslo (Norway) and Iceland.

In 2018, 23 aviation events from Latvia, Georgia, Poland (3 events), Belgium, the Czech Republic (2), Taiwan, Australia (2), Finland, the United Kingdom, Malta, Switzerland (3), Denmark, Portugal (3), Slovakia, and Spain were conveyed to the IHR NFP. Of all the events, 11 concerned the exposure of people from Poland to contact with a person suffering from measles during air travel. In all these events, 52 people from Poland who were exposed to measles cases during flights were identified. In 2018, there were also 3 incidents, where a person from Poland was an index case (Table II).

The remaining nine aviation events that were notified to the IHR NFP were events without the participation of Poles regarding measles cases in people who traveled by plane during the infectious period. The first incident concerned a child with measles, who, during the infectious period (i.e. from December 12, 2017 to December 29, 2017), travelled together with his family by plane on two intercontinental flights and two European flights: from Riga (Latvia) to Phuket (Thailand) and from Phuket to Riga via Moscow. In association with this event, the IHR NFP was also notified of two confirmed cases of measles among the personnel of the Riga International Airport. Since the boy was at the airport in Riga on December 12, 2017, the incubation period corresponded to the incubation period of the two confirmed measles cases at the airport, so it was not possible to rule out a common source of infection. On December 30, 2017, the boy's brother became ill and was diagnosed with measles. The second event concerned a case of measles in Belgium, who, during the infectious period (February 28, 2018), took a European flight from Tirana (Albania) to Zaventem (Belgium). The next event concerned a confirmed case of measles in a Czech person who had a European flight from Athens (Greece) to Prague (Czech Republic) on March 21, 2018, which he took during his infectious period. The fourth event concerned two cases of measles in unvaccinated people from Finland. The first of them was a 27-year-old who had an intercontinental flight to Sri Lanka and Thailand, and on April 16, 2018, he returned to Helsinki (Finland) via Moscow (Russia). na terenie kraju na kontakt z osobą chorą na odrę podczas lotu. We wszystkich tych zdarzeniach odnotowano 52 osoby z Polski, które zostały narażone na kontakt z osobą chorą na odrę podczas lotu. W $2018 \mathrm{r}$. odnotowano również 3 zdarzenia, gdzie osoba z Polski była przypadkiem indeksowym. (tab. II).

Pozostałe dziewięć zdarzeń lotniczych, o których został powiadomiony KPC ds. MPZ to zdarzenia bez udziału Polaków, dotyczące zachorowań na odrę osób, które w okresie zaraźliwości podróżowały samolotem. Pierwsze zdarzenie dotyczyło zachorowania dziecka, które w okresie zaraźliwości (tj. od 12.12.2017 do 29.12.2017) wraz z rodziną odbyło dwa loty międzykontynentalne oraz dwa loty europejskie: z Rygi (Lotwa) do Phuket (Tajlandia) oraz z Phuket do Rygi przez Moskwę. W związku z tym zdarzeniem, KPC ds. MPZ został powiadomiony również o dwóch potwierdzonych przypadkach odry wśród personelu międzynarodowego lotniska w Rydze. Ponieważ chłopiec znajdował się na lotnisku w Rydze w dniu 12.12.2017, okres wylęgania odpowiadał okresowi wylęgania dwóch zachorowań na lotnisku, nie można było więc wykluczyć wspólnego źródła zakażenia. W dniu 30 grudnia 2017 r. zachorował również brat chłopca, u którego potwierdzono zachorowanie na odrę. Drugie zdarzenie dotyczyło przypadku odry u mieszkańca Belgii, który w okresie zakaźności (28 lutego 2018 r.) odbył lot europejski z Tirany (Albania) do Zaventem (Belgia). Kolejne zdarzenie dotyczyło potwierdzonego przypadku odry, u osoby z Czech, która podczas okresu zaraźliwości odbyła lot europejski zAten (Grecja) do Pragi (Czechy) w dniu 21 marca 2018 r. Czwarte zdarzenie dotyczyło dwóch przypadków odry u osób niezaszczepionych z Finlandii. Pierwszy z nich dotyczył 27-letniej osoby, która odbyła lot międzykontynentalny do Sri Lanki oraz Tajlandii, a w dniu 16 kwietnia 2018 r. powróciła do Helsinek (Finlandia) przez Moskwę (Rosja). Drugi przypadek dotyczył 9-miesięcznego dziecka, które z rodzicami odbyło lot międzykontynentalny do Tajlandii i w dniu 16 kwietnia wróciło bezpośrednim lotem z Bangkoku do Helsinek. Prawdopodobnie do narażenia doszło na lotnisku Suvarnabhumi w Bangkoku w dniu 16 kwietnia 2018 r. Kolejne zdarzenie lotnicze, o którym został powiadomiony KPC ds. MPZ, związane było z wystąpieniem dwóch ognisk odry w Lizbonie. Przypadki indeksowe w obydwu ogniskach dotyczyły osób, które odbyły lot europejski - odpowiednio do Ukrainy oraz do Czech. Szóste zdarzenie dotyczyło potwierdzonego laboratoryjnie przypadku odry u osoby, która w dniu 26 listopada 2018 r. odbyła lot kontynentalny z Hongkongu do Pekinu (Chiny), a następnie lot międzykontynentalny z Pekinu do Wiednia (Austria) w dniu 27 listopada 2018 r. Zachorował obywatel Ukrainy, tymczasowo mieszkający w Czechach, który najprawdopodobniej zakaził się podczas pobytu na Ukrainie. Siódme zdarzenie doty- 


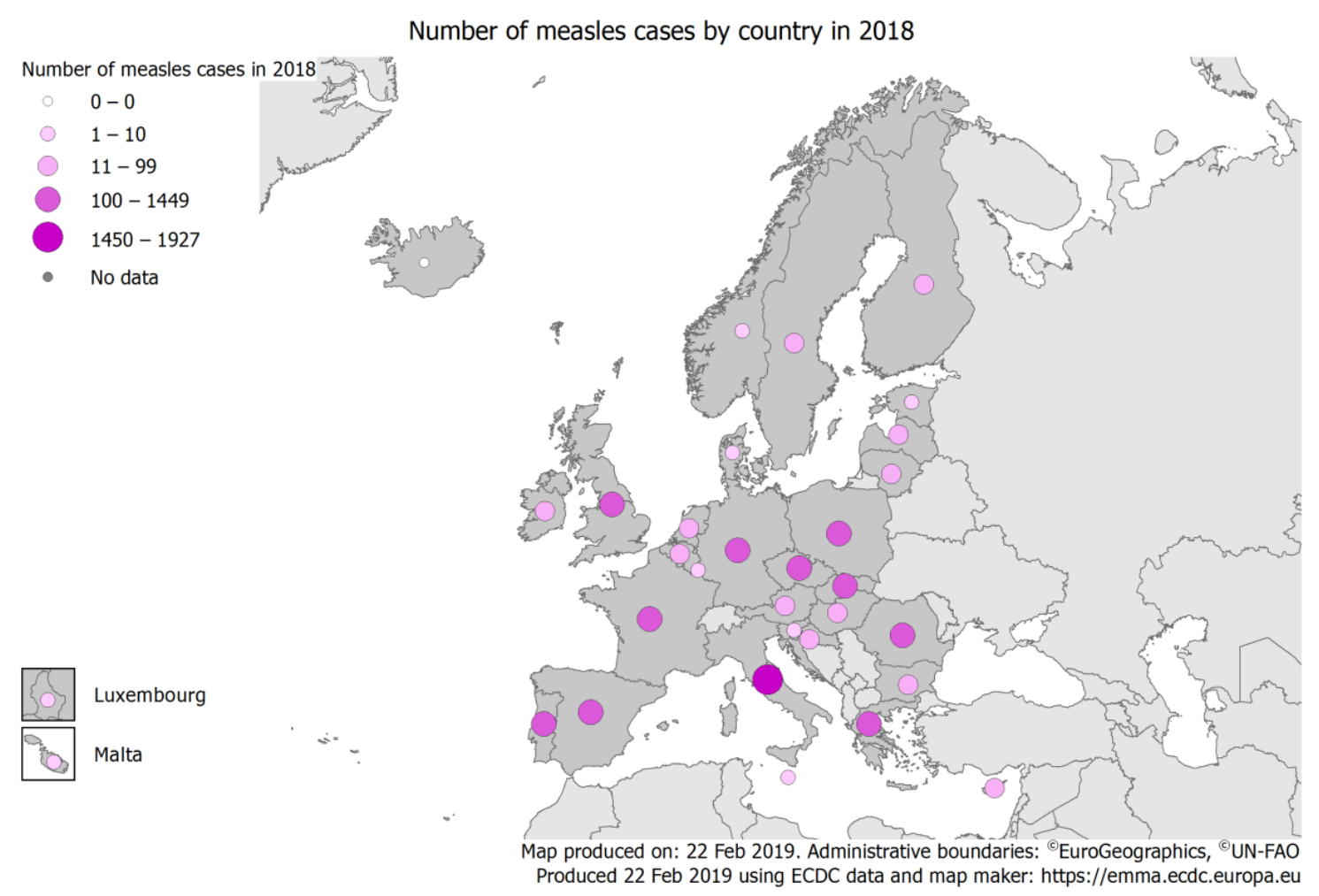

Fig. 3 The number of measles cases by country notified by The European Surveillance System TESSy in 2018. Ryc. 3 Liczba przypadków odry odnotowanych w ramach europejskiego systemu nadzoru TESSy w 2018 roku.

The second case concerned a 9-month-old child who had an intercontinental flight to Thailand with their parents and on April 16 returned by direct flight from Bangkok to Helsinki. Most likely, the exposure occurred at Suvarnabhumi airport in Bangkok on April 16, 2018. The next aviation event, about which the IHR NFP was notified, was associated with the occurrence of two outbreaks of measles in Lisbon. Index cases in both outbreaks concerned people who had taken a European flight - to Ukraine and the Czech Republic respectively. The sixth event included a laboratory confirmed case of measles in a person who on November 26, 2018 had a continental flight from Hong Kong to Beijing (China), followed by an intercontinental flight from Beijing to Vienna (Austria) on November 27, 2018. The case was a citizen of Ukraine, temporarily living in the Czech Republic, who most probably was infected during his stay in Ukraine. The seventh event concerned a laboratory confirmed measles case in a person who had one continental flight from Hanoi (Vietnam) to Taipei (Taiwan) and one intercontinental from Taipei to Vienna. The case occurred in a 29-year-old pregnant woman from Vietnam who currently lives in Slovakia (Nitra region). Another incident concerned an airline employee who had taken many domestic and international flights during the infectious period. As a result of the conducted epidemiological investigation, there were 7 confirmed or probable cases of measles identified among the flight crew of the same company as well as the index czyło potwierdzonego laboratoryjnie przypadku odry u osoby, która odbyła jeden lot kontynentalny z Hanoi (Wietnam) do Tajpej (Tajwan) i jeden międzykontynentalny z Tajpej do Wiednia. Zachorowanie wystąpiło u pochodzącej z Wietnamu, 29-letniej ciężarnej kobiety, która obecnie mieszka na Słowacji (region Nitra). Kolejne zdarzenie dotyczyło pracownika linii lotniczych, który odbył wiele lotów krajowych i międzynarodowych podczas okresu zaraźliwości. W wyniku przeprowadzonego dochodzenia epidemiologicznego odnotowano 7 potwierdzonych lub prawdopodobnych przypadków odry wśród załogi pokładowej tego samego przewoźnika oraz przypadek indeksowy, którym okazał się pasażer. Wszyscy chorzy podróżowali lotami krajowymi oraz międzynarodowymi podczas okresu zaraźliwości. Ponadto KPC ds. MPZ został powiadomiony o jednym, potwierdzonym laboratoryjnie, zawleczonym przypadku odry z Londynu na wyspę Madera (Portugalia). Była to niezaszczepiona kobieta, która mieszka i pracuje w Londynie i odbyła lot kontynentalny do Funchal.

\section{DYSKUSJA}

W latach 2016-2018 KPC ds. MPZ odnotowal 92 zdarzenia dotyczące odry, [podczas gdy w latach 2010-2016 liczba zdarzeń wynosiła 79 (15)]. Wśród nich były zgłoszenia dotyczące wystąpienia ognisk zachorowań, pojedynczych przypadków zachorowań oraz dotyczące wystąpienia narażenia na styczność 
case, which turned out to be a passenger. All patients traveled on domestic and international flights during the infectious period. In addition, the IHR NFP was notified about one laboratory confirmed case of measles from London to the island of Madeira (Portugal). The case concerned an unvaccinated woman who lived and worked in London and took a continental flight to Funchal.

\section{DISCUSSION}

In the years 2016-2018, the IHR NFP recorded 92 events related to measles [while in 2010-2016 the number of events was 79 (15)]. Among them were reports of outbreaks, individual cases and the occurrence of exposure to a person with measles. The IHR NFP observed three times more events in 2018 (63 events) than in 2017 (21 events) and almost eight times more than in 2016 ( 8 events). The number of events related to all three categories - individual cases of measles, outbreaks, and exposure to contact with a person suffering from measles - increased each year. Information on measles outbreaks reached the IHR NFP from all WHO regions.

With the increase in the incidence of measles around the world, especially in the European region, increases the number of reported events that may cause the introduction of measles into the Polish population, such as exposure to ill persons abroad or during air travel, as well as outbreaks among mobile groups (Roma population). Moreover, with the increase in the overall number of measles-related events, the number of measles outbreaks in Poland also increased. This indicates a direct relationship between the epidemiological situation in Europe and the threat of increased incidence in Poland. The presented data indicates the necessity of meticulous implementation of the National Vaccination Program as well as the implementation of emergency vaccination, which was enabled in Poland by the introduction of the Regulation of the Minister of Health of September 6, 2016 on methods of measles prevention. This regulation covers unvaccinated persons and those without vaccine documentation, regardless of their age, who remain in an environment with a low percentage of vaccinated people and who have been or may be exposed to a person with or suspected of having measles (16).

In Poland, there is observed a systematic increase in the number of people avoiding compulsory vaccinations, as indicated by data in individual years (2010 - 3 437, 2011 - 4 689, 2012 - 5 340, 2013 $7248,2014-12681,2015-16689,2016-23147$, 2017 - 30 090) (17). In 2018 (as of 30.06.2018), 34273 abstentions were registered, more than in the whole z osobą chorą na odrę. KPC ds. MPZ odnotował trzykrotnie większą liczbę zdarzeń w roku 2018 (63 zdarzenia), niż w 2017 (21 zdarzeń) i prawie ośmiokrotnie większą, niż w 2016 (8 zdarzeń). Zarówno liczba zdarzeń związanych z pojedynczymi przypadkami zachorowań na odrę, jak i liczba ognisk oraz liczba narażeń na kontakt $\mathrm{z}$ osobą chorą na odrę każdego roku wzrastały. Informacje o ogniskach zachorowań na odrę dotarły do KPC ds. MPZ ze wszystkich regionów WHO.

Wraz ze wzrostem zachorowalności na odrę na świecie, a zwłaszcza w regionie europejskim, zwiększa się liczba zgłaszanych zdarzeń, które mogą spowodować introdukcję odry do populacji polskiej, takich jak narażenia na kontakt z osobami chorymi za granicą lub podczas podróży lotniczych, jak również ogniska wśród grup mobilnych (populacja romska). Ponadto, wraz ze wzrostem ogólnej liczby zdarzeń związanych z odrą wzrosła również liczba zdarzeń dotyczących ognisk odry w Polsce. Wskazuje to na bezpośredni związek sytuacji epidemiologicznej w Europie z zagrożeniem wzrostem zapadalności w Polsce. Przedstawione dane wskazują na konieczność skrupulatnej realizacji krajowego Programu Szczepień Ochronnych oraz wdrażania szczepień interwencyjnych, co w Polsce umożliwiło wprowadzenie rozporządzenia Ministra Zdrowia z dnia 6 września 2016 r. w sprawie metody zapobiegania odrze. Dzięki niemu szczepieniami są objęte osoby niezaszczepione lub niemające udokumentowanego szczepienia, bez względu na ich wiek, które przebywają w środowisku o niskim odsetku osób zaszczepionych oraz były lub mogą być narażone na styczność $\mathrm{z}$ osobą chorą lub podejrzaną o zachorowanie na odrę (16).

W Polsce notowany jest systematyczny wzrost liczby osób uchylających się od obowiązkowych szczepień, na co wskazują dane $\mathrm{w}$ poszczególnych latach $(2010$ - 3437, 2011 - 4 689, 2012 - 5 340, 2013 - 7 248; 2014 - 12 681; 2015 - 16 689, 2016 23 147, 2017 - 30 090) (17). W 2018 r. (stan na dzień 30.06.2018 r.) odnotowano 34273 uchylenia od szczepień, więcej niż w całym 2017 r. (18). W 2016 roku odsetek dzieci urodzonych w latach 2015 oraz 2016, nieobjętych szczepieniem podstawowym szczepionką MMR wynosił 22,6\% w skali kraju (17). W 2017 r. stan zaszczepienia przeciwko odrze odnotowano na poziomie 94\% dla podstawowej dawki szczepionki MMR, natomiast dla dawki przypominającej 93\% (17).

Spośród wszystkich przypadków odry z państw UE/EOG w 2017 r. 12160 miało charakter endemiczny, 1173 miało związek z przypadkami zawleczonymi, natomiast 383 uznano jako zawleczone. 37\% zachorowań na odrę wystąpiło dzieci poniżej 5 roku życia, a 45\% wszystkich zachorowań dotyczyło osób 
year of 2017 (18). In 2016, the percentage of children born in 2015 and 2016 who were not vaccinated with the basic MMR vaccine was $22.6 \%$ in the country (17). In 2017, measles inoculation was recorded at $94 \%$ for the baseline dose of MMR, and $93 \%$ for the booster dose (17).

Of all measles cases in the EU/EEA in 2017, 12160 were endemic, 1173 were linked to imported cases, while 383 were considered to have been imported. $37 \%$ of measles cases concerned children under 5 years of age, and $45 \%$ of all cases affected people aged 15 and higher. The highest incidence rate was observed in children under 1-year-old (36.6/100 000 people) (6).

In several EU/EEA countries in 2017 and at the beginning of 2018 (current status as of 21.03.2018), cases were also detected among healthcare workers, including Belgium (35 cases), the Czech Republic (20), Italy (315), Greece (67) and Norway (2). Measles cases in health care facilities have also been reported in countries with high levels of inoculation: Sweden (1 case) and Portugal (28). Health care workers may be involved in the transmission of the measles virus because they are exposed to contact with infected patients as well as susceptible newborns or immunocompromised patients. Some countries, such as Denmark or Sweden, have taken specific measures to facilitate the availability of vaccinations for unvaccinated adults and health professionals (6).

According to an ECDC risk assessment from 2018, EU/EEA measles cases occur mainly in non-vaccinated populations, both adults and children. In countries where the transmission of the measles virus has been eliminated or interrupted, a large number of cases are currently present, including fatal ones. Even in countries with over $95 \%$ inoculation, some communities may have measles outbreaks. In some countries, an increasing percentage of cases have been observed in adults, which necessitates considering the introduction of additional vaccination campaigns. Given the current spread of measles in EU/EEA countries, the increasing number of cases in recent years and the suboptimal inoculation status of some populations, there is a high risk of further measles transmission between EU/EEA Member States and other countries (6). The ECDC report published in February 2019 for the entire year 2018 showed 12352 measles cases reported, with the highest amounts in France (2 913), Italy (2 517) and Greece (2 293) (Figure 3). 79\% of people who fell ill were not vaccinated against measles, and $15 \%$ were vaccinated with only one dose of vaccine (9).

Currently in Poland there is a large inflow of people from abroad. According to the data of the Office for Foreigners, in 2018 the highest percentage of foreigners registered in Poland were people from Ukraine (48\% - 179080 people). In comparison, even w wieku 15 lat i powyżej. Najwyższą zapadalność odnotowano u dzieci poniżej pierwszego roku życia (36,6/100 000 osób) (6).

W kilku państwach UE/EOG w 2017 r. i na początku 2018 r. (stan aktualny na dzień 21.03.2018 r.) stwierdzono również zachorowania wśród pracowników ochrony zdrowia, w tym w Belgii (35 przypadków), Czechach (20), Włoszech (315), Grecji (67) i Norwegii (2). Zachorowania w placówkach ochrony zdrowia odnotowano też w państwach o wysokim stanie zaszczepienia: w Szwecji (1 przypadek) i Portugalii (28). Pracownicy ochrony zdrowia mogą mieć udział $\mathrm{w}$ transmisji wirusa odry, ponieważ są narażeni na styczność zarówno z osobami zakażonymi, jak i podatnymi na zakażenie noworodkami, czy z pacjentami z obniżoną odpornością. Niektóre państwa, jak np. Dania, czy Szwecja podjęły szczególne działania mające na celu ułatwienie dostępności do szczepień osobom dorosłym niezaszczepionym w pełni oraz pracownikom ochrony zdrowia (6).

Według oceny ryzyka ECDC z 2018 roku, przypadki odry w UE/EOG występują głównie w niezaszczepionych populacjach, zarówno wśród dorosłych, jak i u dzieci. W państwach, gdzie udało się wyeliminować lub przerwać transmisję wirusa odry, obecnie notuje się występowanie dużej liczby zachorowań, wśród których zdarzają się również przypadki śmiertelne. Nawet w państwach o stanie zaszczepienia powyżej 95\% w niektórych społecznościach mogą występować ogniska odry. W niektórych krajach zaobserwowano wzrastający odsetek przypadków wśród dorosłych, co powoduje rozważenie wprowadzenia kampanii dodatkowych szczepień. Biorąc pod uwagę aktualne rozprzestrzenienie odry w państwach UE/EOG, wzrastającą w ostatnich latach liczbę przypadków oraz suboptymalny stan zaszczepienia niektórych populacji, istnieje wysokie ryzyko dalszej transmisji odry między państwami członkowskimi UE/EOG a państwami trzecimi (6). W opublikowanym w lutym 2019 roku raporcie ECDC dotyczącym całego roku 2018 odnotowano 12352 przypadki odry, najwięcej we Francji (2 913), Włoszech (2 517) i Grecji (2 293) (Ryc. 3). 79\% osób, które zachorowały nie było zaszczepionych przeciwko odrze, a $15 \%$ zostało zaszczepionych jedną dawką szczepionki (19).

Obecnie w Polsce występuje duży napływ osób z zagranicy. Według danych Urzędu ds. Cudzoziemców, w 2018 r. największy odsetek cudzoziemców zarejestrowanych w Polsce stanowiły osoby z Ukrainy (48\% - 179080 osób). Dla porównania, jeszcze 5 lat temu, w 2014 r. osoby z Ukrainy stanowiły 18,35\% cudzoziemców oraz liczba obywateli Ukrainy zarejestrowanych przez Urząd ds. Cudzoziemców wynosiła 24862 osoby (20). Prawdopodobnie w wyniku tego zjawiska, KPC ds. MPZ zaobserwował w 2018 r. 
5 years ago, in 2014, people from Ukraine accounted for $18.35 \%$ of foreigners and the number of Ukrainian citizens registered by the Office for Foreigners amounted to 24862 people (20). Most likely as a result of this phenomenon, in 2018 the IHR NFP observed an increase in the number of events in Poland concerning measles with the participation of people of Ukrainian citizenship or with people who were staying in Ukraine before falling ill. In 2018, 15 such events occurred, while in 2017 no similar situation was reported from Poland.

The review of events carried out by the authors as well as the situation in Poland and in the world give grounds to claim that in the coming years there will be more measles outbreaks in Poland, in which index cases may not only be citizens of countries where measles outbreaks are present, but also travelling Polish citizens exposed to measles.

\section{CONCLUSIONS}

1. The number of events related to measles, recorded by the IHR NFP in Poland in 2016-2018, has been increasing.

2. The number of events related to measles outbreaks in Poland in 2016-2018, recorded by the IHR NFP has been increasing.

3. There is a direct connection between the epidemiological situation in Europe and in countries bordering Poland with the threat of an increase in the incidence of measles in Poland.

4. The number of aviation events concerning measles in 2016-2018, recorded by the IHR NFP has been increasing.

5. The majority of measles cases related to events recorded by the IHR NFP occurred in people unvaccinated against this disease.

\section{REFERENCES}

1. Szenbron L, Sawiec P, Odra. W: Gajewski P, red. Interna Szczeklika. Kraków: Medycyna Praktyczna; 2015: 2308-2309.

2. World Health Organization. Global Vaccine Action Plan 2011-2020. http://bit.do/eBXgv, [accessed 29.11.2018]

3. World Health Organization. 2018 Assessment Report of the Global Vaccine Action Plan. http://bit.do/eBXe4, [accessed 23.11.2018]

4. World Health Organization. Measles in Europe: record number of both sick and immunized. Genewa: WHO; 2019, https://bit.ly/2TBeXcw, [accessed 22.02.2019]

5. World Health Organization. A monthly summary of the epidemiological data on selected Vaccinepreventable diseases in the WHO European Region. 01.02.2019. http://www.euro.who.int/_data/assets/pdf file/0004/394060/2019_01_Epi_Data_EN_Jan-Dec-2018. pdf?ua $=1$, [accessed 28.02.2019] wzrost liczby zdarzeń w Polsce dotyczących odry z udziałem osób obywatelstwa ukraińskiego lub z osobami, które przebywały na Ukrainie przed zachorowaniem. W 2018 r. wystąpiło 15 takich zdarzeń, natomiast w 2017 r. nie zgłoszono żadnej podobnej sytuacji z terenu Polski.

Przeprowadzony przez autorów przegląd zdarzeń oraz sytuacja w Polsce i na świecie dają podstawy do twierdzenia, iż w najbliższych latach w Polsce będzie dochodziło do występowania ognisk odry, w których przypadkami indeksowymi mogą być nie tylko obywatele państw, w których trwają ogniska odry, ale również podróżujący polscy obywatele narażeni na kontakt z odrą.

\section{WNIOSKI}

1. Liczba wszystkich zdarzeń dotyczących odry, odnotowanych przez polski KPC ds. MPZ w latach 2016 - 2018 wzrastała.

2. Liczba zdarzeń dotyczących ognisk odry w Polsce w latach 2016 - 2018, odnotowanych przez polski KPC ds. MPZ wzrastała.

3. Występuje bezpośredni związek sytuacji epidemiologicznej odry w Europie oraz w państwach graniczących z Polską z zagrożeniem wzrostem zapadalności na odrę w Polsce.

4. Liczba zdarzeń lotniczych dotyczących odry w latach 2016 - 2018, odnotowanych przez polski KPC ds. MPZ wzrastała.

5. Większość przypadków zachorowań na odrę ze zdarzeń odnotowanych przez polski KPC ds. MPZ wystąpiła u osób nieszczepionych przeciwko tej chorobie.

6. European Centre for Disease Prevention and Control. Rapid risk assessment: Risk of measles transmission in the EU/EEA. Stockholm: ECDC; 21.03.2018. http://bit. do/eBXfj, [accessed 29.11.2018]

7. Bogusz J., Paradowska-Stankiewicz I. Measles in Poland in 2016. Epidemiological Review 2018;72:267 -274 .

8. National Institute of Public Health - National Institute of Hygiene, Chief Sanitary Inspectorate Infectious diseases and poisonings in Poland in 2017. http:// wwwold.pzh.gov.pl/oldpage/epimeld/2017/Ch_2017. pdf, [accessed 23.11.2018]

9. National Institute of Public Health - National Institute of Hygiene, Chief Sanitary Inspectorate. Cases of selected infectious diseases in Poland from January $1^{\text {st }}$ to December $31^{\text {st }}, 2018$ and in the analogous period of 2017. http://wwwold.pzh.gov.pl/oldpage/epimeld/2018/ INF_18_12B.pdf, [accessed 29.11.2018]

10. Kicman-Gawłowska A. The surveillance of communicable diseases within the International Health Regulations (2005). Epidemiological Review 2008;62:739 749 . 
11. World Health Organization. International Health Regulations. 2015. http://bit.do/eBXfc, [accessed 23.11.2018]

12. European Centre for Disease Prevention and Control. Rapid risk assessment: ongoing outbreak of measles in Romania, risk of spread and epidemiological situation in EU/EEA countries. Stockholm: ECDC; 3.03.2017. http://bit.do/eBXfq, [accessed 29.11.2018]

13. Tłoczyński D. Directions of air transport development, https://www.ue.katowice.pl/fileadmin/_migrated/ content_uploads/33_D.Tloczynski_Kierunki_rozwoju_ transportu....pdf, [accessed 22.02.2019]

14. Suska E., et al. Risks of epidemics posed by today's civil aviation. Hygeia Public Health;53(4):348-355.

15. Izdebski R., et al. Measles elimination - review of event notifications sent to National IHR Focal Point between 2010 and 2016. Epidemiological Review 2017;71:15-24.

16. Regulation of the Minister of Health of September $6^{\text {th }}$, 2016 on methods of measles prevention, Dz. U. 2016 poz. 1418.

17. National Institute of Public Health - National Institute of Hygiene, Chief Sanitary Inspectorate. Vaccinations in Poland (years 2010-2017). http://wwwold.pzh. gov.pl/oldpage/epimeld/index_p.html\#05, [accessed 29.11.2018]

18. National Institute of Public Health - National Institute of Hygiene. Where can you find information on the number of abstentions from mandatory vaccinations?, http://bit.do/eB5ey, [accessed 30.11.2018]
19. European Centre for Disease Prevention and Control. Monthly measles and rubella monitoring report. Stockholm: ECDC; 8.02.2019. http://ecdc.europa.eu/ sites/portal/files/documents/measles-rubella-monthlymonitoring-report-february-2019.pdf, [accessed 25.02.2019]

20. Office for Foreigners. Maps and statistics of migrants and Polish migration services, https://migracje.gov.pl/, [accessed 15.01.2019]

Received: 4.12.2018

Accepted for publication: 12.03.2019

Otrzymano: 4.12.2018 r.

Zaakceptowano do publikacji: 12.03.2019 r.

\section{Address for correspondence:}

Adres do korespondencji:

Paulina Maria Nowicka

National IHR Focal Point

National Institute of Public Health - National Institute of

Hygiene

Department of Epidemiology

24 Chocimska st., 00-791 Warsaw, Poland

e-mail: pnowicka@pzh.gov.pl 